\title{
1 Direct activation of endothelial cells by SARS-CoV-2 nucleocapsid protein is blocked by
}

\section{Simvastatin}

4 Yisong Qian ${ }^{1,2}$, Tianhua Lei ${ }^{1}$, Parth S. Patel ${ }^{1}$, Chi H Lee ${ }^{3}$, Paula Monaghan-Nichols ${ }^{1}$, Hong-Bo Xin ${ }^{2}$, Jianming $5 \mathrm{Qiu}^{4}$, and Mingui $\mathrm{Fu}^{1+}$

$7{ }^{1}$ Department of Biomedical Sciences and Shock/Trauma Research Center, School of Medicine, University of

8 Missouri Kansas City, 2411 Holmes Street, Kansas City, MO 64108. ${ }^{2}$ The National Engineering Research

9 Center for Bioengineering Drugs and the Technologies, Institute of Translational Medicine, Nanchang

10 University, 1299 Xuefu Rd, Honggu District, Nanchang, 330031, China. ${ }^{3}$ Department of Pharmaceutics, School

11 of Pharmacy, University of Missouri Kansas City, 2464 Charlotte Street, Kansas City, $64108 ;{ }^{4}$ Department of

12 Microbiology, Molecular Genetics and Immunology, University of Kansas Medical Center, 3901 Rainbow

13 Boulevard, Kansas City, KS 66160

$15 \$$ Address correspondence to Mingui Fu, Department of Biomedical Sciences and Shock/Trauma Research

16 Center, School of Medicine, University of Missouri Kansas City, 2411 Holmes Street, Kansas City, MO 64108.

17 Tel.: 816-235-2193; Fax: 816-235-6444; E-mail: fum@umkc.edu.

19 Running head: N protein activates endothelial cells

21 Total character count in the manuscript: 8796

22 The character count includes ALL sections except the Materials and Methods and References: 6458 


\section{ABSTRCT}

Emerging evidence suggests that endothelial activation plays a central role in the pathogenesis of acute respiratory distress syndrome (ARDS) and multi-organ failure in patients with COVID-19. However, the molecular mechanisms underlying endothelial activation in COVID-19 patients remain unclear. In this study, the SARS-CoV-2 viral proteins that potently activate human endothelial cells were screened to elucidate the molecular mechanisms involved with endothelial activation. It was found that nucleocapsid protein (NP) of SARS-CoV-2 significantly activated human endothelial cells through TLR2/NF- $\mathrm{B}$ and MAPK signaling pathways. Moreover, by screening a natural microbial compound library containing 154 natural compounds, simvastatin was identified as a potent inhibitor of NP-induced endothelial activation. Remarkablely, though the protein sequences of $\mathrm{N}$ proteins from coronaviruses are highly conserved, only NP from SARS-CoV-2 induced endothelial activation. The NPs from other coronaviruses such as SARS-CoV, MERS-CoV, HUB1-CoV and influenza virus H1N1 did not affect endothelial activation. These findings are well consistent with the results from clinical investigations showing broad endotheliitis and organ injury in severe COVID-19 patients. In conclusion,

41 the study provides insights on SARS-CoV-2-induced vasculopathy and coagulopathy, and suggests that 42 simvastatin, an FDA-approved lipid-lowering drug, may benefit to prevent the pathogenesis and improve the outcome of COVID-19 patients.

Key words: COVID-19, SARS-CoV-2, Nucleocapsid protein, endothelial activation, simvastatin. 


\section{INTRODUCTION}

55 The emergence of severe acute respiratory syndrome coronavirus 2 (SARS-CoV-2), which causes the coronavirus

56 disease 2019 (COVID-19), triggered a global pandemic that has led to an unprecedented worldwide public health

57 crisis $^{1}$. Before SARS-CoV-2, two other highly pathogenic coronaviruses emerged in the past two decades,

58 including severe acute respiratory syndrome coronavirus (SARS-CoV) ${ }^{2}$ and Middle East respiratory syndrome

59 coronavirus (MERS-CoV) ${ }^{3}$. In addition, four endemic human coronaviruses (i.e., OC43, 229E, NL63 and HKU1)

60 cause common cold respiratory diseases ${ }^{4}$. COVID-19 is characterized by progressive respiratory failure resulting

61 from diffuse alveolar damage, inflammatory infiltrates, endotheliitis, and pulmonary and systemic coagulopathy

62 forming obstructive microthrombi with multiorgan dysfunction ${ }^{5-8}$. Pathological findings of cell swelling, severe

63 endothelial injury, disruption of intercellular junctions, and basal membrane contact loss in COVID-19 patients

64 imply that the destruction of endothelial cells (ECs) leads to pulmonary vascular endotheliitis and alveolar

65 capillary microthrombi ${ }^{9-12}$. Together, emerging evidence suggests that endothelial activation is an early hallmark

66 of multiorgan damage in patients with COVID-19 $9^{13}$. Moreover, thrombotic complications are a relevant cause of

67 death in patients with COVID-19 ${ }^{14}$. Therefore, understanding the molecular mechanisms of the endothelial

68 activation caused by SARS-CoV-2 and pathways involved in the regulation of endothelial dysfunction could lead

69 to new therapeutic strategies against COVID-19.

70 SARS-CoV-2 infects the host using angiotensin converting enzyme 2 (ACE2) as its receptor ${ }^{15}$. ACE2 is an

71 integral membrane protein that is expressed by airways and lung alveolar epithelial cells, enterocytes, and

72 vascular endothelial cells ${ }^{16}$. Though the primary target tissues of SARS-CoV-2 are airways and lungs, there is also

73 evidence of direct viral infection of endothelial cells and diffuse endothelial inflammation in COVID-19 disease ${ }^{17}$.

74 Moreover, vulnerable patients with pre-existing endothelial dysfunction, which is associated with male sex,

75 smoking, hypertension, diabetes and obesity and established cardiovascular disease, are associated with adverse

76 outcomes in COVID- $19^{18}$. Together, these clinical findings suggest that endothelial cells play a central role in the

77 pathogenesis of ARDS and multi-organ failure in patients with COVID-19. Therefore, the vascular system is

78 increasingly being addressed as a major therapeutic target for defeating COVID-19. 
The potential molecular mechanisms that SARS-CoV-2 induces endothelial activation, dysfunction and injury may contribute to the direct toxic effect of viral proteins. The genome of SARS-CoV-2 encodes 29 viral proteins including 16 non-structure proteins (NSP1-NSP16), 4 structure proteins including spike (S), membrane (M), nucleocapsid $(\mathrm{N})$ and envelope $(\mathrm{E})$ proteins and 9 accessory proteins ${ }^{19,20}$. Though their functions in viral lifecycle are increasingly studied, their impacts on host cells are largely unknown. To determine whether distinct viral proteins can induce endothelial activation, recombinant SARS-CoV-2 proteins were evaluated for their potential to activate human endothelial cells. We found that $\mathrm{N}$ protein potently induced endothelial activation via Toll-like receptor 2 (TLR2)/NF- $\mathrm{BB}$ and MAPK signal pathways. To identify potential therapeutic agents targeting $\mathrm{N}$ protein-induced endothelial activation, a natural microbial compound library containing 154 natural compounds was screened and a single drug, simvastatin, was identified as specific inhibitor of $\mathrm{N}$ protein-induced endothelial activation. These results suggest that $\mathrm{N}$ protein released from SARS-CoV-2-infected cells may contribute to the broad activation of endothelium and tissue inflammation and simvastatin may benefit to prevent the viral infection-induced pathogenesis and improve the outcome of COVID-19 patients.

\section{RESULTS}

Identification of nucleocapsid protein (NP) as a potent inducer of human endothelial cell activation

To understand the molecular mechanisms that SARS-CoV-2 induces endothelial activation, we purchased eight recombinant SARS-CoV-2 viral proteins, including three structural proteins (S, N, and E proteins) and five nonstructural proteins (NSP1, NSP3, NSP5, NSP7 and NSP8). The proteins were added to human primary lung microvascular endothelial cells (HLMECs) for 8 hours. Western blotting was used to analyze the expression of ICAM-1 and VCAM-1, the markers of endothelial cell activation. As shown in Fig.1a, N protein significantly

100 induced the expression of ICAM-1 and VCAM-1. TNF $\alpha$ is the most potent endogenous inducer of endothelial 101 activation, which serves as a positive control. To further confirm the effect of $\mathrm{N}$ protein on endothelial cell 102 activation, we incubated HLMECs with different doses of $\mathrm{N}$ protein or for different incubation periods. As shown 103 in Fig.1b, N protein induced ICAM-1 expression at 4 hours and continued to increase up to 24 hours, which was 104 similar to the expression pattern induced by TNF $\alpha$. Similar pattern of expression of VCAM-1 was also induced by 
$105 \mathrm{~N}$ protein. However, the expression of VE-cadherin, an EC junction structure protein, was not changed. In

106 addition, $\mathrm{N}$ protein significantly induced ICAM-1 expression at $0.05 \mu \mathrm{g} / \mathrm{ml}$ and more potent at $1 \mu \mathrm{g} / \mathrm{ml}$, which is 107 comparable with the effect of TNF $\alpha$ at $10 \mathrm{ng} / \mathrm{ml}$ (Fig.1c). Next, we tested whether $\mathrm{N}$ protein also induced 108 activation of other endothelial cells. Human umbilical vein endothelial cells (HUVEC), human aortic endothelial 109 cells (HAEC), human coronal artery endothelial cells (HCAEC), human dermal microvascular endothelial cells 110 (HDMEC), HLMEC, 293T, A549 and mouse lung vascular endothelial cells (MEC) were incubated with $1 \mu \mathrm{g} / \mathrm{ml}$ 111 of N protein for 8 hours. As shown in Fig.1d, N protein significantly induced activation of all human endothelial 112 cells tested, but not induced expression of ICAM-1 and VCAM-1 in 293T, A549 and mouse endothelial cells. We 113 also probed the same blot using anti-mouse ICAM-1 and VCAM-1 antibodies, respectively, and confirmed that N 114 protein did not induced mouse EC activation. To further confirm whether $\mathrm{N}$ protein induce the expression of 115 adhesion molecules and proinflammatory cytokines at transcriptional level, we examined the changes of ICAM-1, 116 VCAM-1, E-selectin, TNF $\alpha$, MCP-1 and IL-1 $\beta$ mRNA levels in NP-treated HLMECs. As shown in Fig.1e, N 117 protein potently induced the expression of adhesion molecules, inflammatory cytokines and chemokines, which is 118 similar to the function of TNF $\alpha$, a potent endogenous inducer of endothelial activation. The expression of ICAM1191 and VCAM-1 on the surface of endothelial cells contributes to the leukocytes adherence on endothelial cells ${ }^{21,22}$. 120 To examine if $\mathrm{N}$ protein also induces the monocyte adherence to activated endothelial cells, HLMECs were 121 stimulated with $\mathrm{N}$ protein $(1 \mu \mathrm{g} / \mathrm{ml})$ or TNF $\alpha(10 \mathrm{ng} / \mathrm{ml})$ for 8 hours and then the Zombie Red fluorescent-labelled 122 human primary monocytes (Lonza) were co-cultured with the activated endothelial cells for 1 hour. After washed, 123 the adherent cells were visualized by a fluorescent microscopy and counted in a double-blind way. As shown in 124 Fig.1f, both N protein and TNF $\alpha$ significantly increased monocyte adherence on ECs, compared with that in 125 control group. Taken together, these results suggest that $\mathrm{N}$ protein is a potent inducer of endothelial cell 126 activation, and it may play a key role in SARS-CoV-2-induced lung inflammation and multi-organ failure.

128 N protein activated NF-кB and MAPK signaling pathways in human endothelial cells

129 It is well known that the expression of ICAM-1 and VCAM-1 was controlled by MAPK and NF- $\mathrm{BB}$ signaling 130 pathways ${ }^{23,24}$. To test if $\mathrm{N}$ protein can activate these signal pathways, HLMECs were incubated with NP $(1 \mu \mathrm{g} / \mathrm{ml})$ 
131 for $0,15,30,45,60$ and $120 \mathrm{~min}$, the cell lysates were analyzed by Western blot. As shown in Fig.2, NP

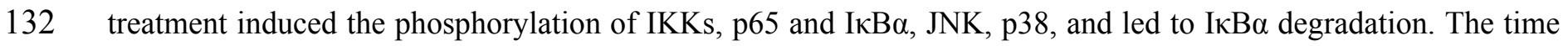
133 patterns of phosphorylation of these signaling molecules were similar to that of TNF $\alpha$-induced activation of the 134 signal pathways. Interested to note that S protein and LPS did not induce activation of NF- $\mathrm{KB}$ signaling, but 135 weakly induced activation of MAPK pathways including ERK1/2, JNK and p38. These results suggest that N 136 protein activated JNK, p38 and NF-אB signal pathways in human endothelial cells.

\section{N protein induced endothelial cell activation via TLR2-mediated signaling pathway}

139 Next, we investigated how N protein activates NF-кB and MAPK signaling pathways in human endothelial cells.

140 First we test if $\mathrm{N}$ protein acts on cell surface receptors or intercellular signal proteins. Pretreatment with the 141 inhibitors of endocytosis such as Pitstop2 and Dynasore hydrate did not affect NP-induced expression of ICAM-1 and VCAM-1 (Fig.3a), suggesting that internalization of $\mathrm{N}$ protein is not required for its action on endothelial activation. Moreover, we transfected the expression plasmid encoding $\mathrm{N}$ protein into HLMECs. Though overexpression of $\mathrm{N}$ protein in endothelial cells, intercellular $\mathrm{N}$ protein did not induce the expression of ICAM-1 and VCAM-1 (Fig.3b). Furthermore, incubation of HLMECs with $\mathrm{N}$ protein for different times showed that $\mathrm{N}$ protein bound to endothelial cells in a time-dependent manner (Fig.3c). These results suggest that $\mathrm{N}$ protein may bind to a kind of receptors on endothelial cells and trigger the NF- $\kappa \mathrm{B}$ and MAPK signal pathways. Next, HLMECs were pretreated with antagonists of TLR2 (CU-CPT22), TLR4 (LPS-RS) and IL-1R (IL-1R antagonist) was detected by Western blotting. As shown in Fig.3a, TLR2 antagonist (CU-CPT22) significantly blocked NP-

151 induced expression of ICAM-1 and VCAM-1 in human endothelial cells, suggesting that N protein may bind to 152 TLR2 to trigger the activation of NF- $\mathrm{KB}$ and MAPK and induce endothelial activation. Fig.3d further showed that 153 CU-CPT22 dose-dependently inhibited NP-induced expression of ICAM-1 and VCAM-1. To further confirm that $154 \mathrm{~N}$ protein is able to activate TLR2, both wild-type 293T cells (without TLR2 expression) and TLR2155 overexpressed $293 \mathrm{~T}$ cells were treated with or without $\mathrm{N}$ protein. As shown in Fig.3e, N protein did not induce 156 phosphorylation of JNK and p38 in wild-type 293T cells. However, N protein significantly induced 
157 phosphorylation of JNK and p38 in 293T-TLR2 cells. Finally, as shown in Fig,3a, pretreatment with the

158 inhibitors of IKK, JNK and p38 completely blocked NP-induced expression of ICAM-1 and VCAM-1. Taken 159 together, these results suggest that $\mathrm{N}$ protein activates endothelial cells via TLR2-mediated NF- $\mathrm{B}$ and MAPK 160 signal pathways.

\section{Identification of simvastatin as an effective inhibitor of $\mathbf{N}$ protein-induced endothelial activation}

163 To screen the inhibitors of $\mathrm{N}$ protein-induced endothelial activation, 154 chemicals from microbial natural 164 product library (Target Molecule, Wellesley Hills, MA) were added into individual wells of 48-well-plates at 30 $165 \mu \mathrm{M} 1$ hour before the induction of $\mathrm{N}$ protein $(1 \mu \mathrm{g} / \mathrm{ml})$. The effect of chemicals on endothelial activation was measured by Western blot with anti-ICAM-1 antibody. Among 154 chemicals, we found that 12 chemicals showed significant inhibition of N protein-induced ICAM-1 expression, which include Simvastatin, Lovastatin, Rapamycin, Cyclosporine A, Menadione, 1, 4-Naphthoquinone, L-Thyroxine, Thiostrepton, Monensin, Amphotericin B, Gramicidin and Abamectin (Fig.4). The later six are antibiotics which are toxic for cells and used in animals, not suitable for human use. Menadione and 1, 4-Naphthoquinone are vitamin $\mathrm{K}$ derivatives, 171 which have anti-bacteria, anti-viral, anti-inflammation activities. Rapamycin and Cyclosporine A are 172 immunosuppressant. Simvastatin and lovastatin are FDA-approved lowering blood lipid drugs with anti173 inflammatory roles.

\section{Simvastatin is an effective inhibitor of $\mathbf{N}$ protein-induced endothelial activation in vitro}

176 To confirm the specific inhibitory role of simvastatin in $\mathrm{N}$ protein-induced endothelial activation, we compared 177 the effect of simvastatin, lovastatin, atorvastatin, mevastatin and rosuvastatin. As shown in Fig.5a, among the five 178 statins tested, simvastatin potently inhibited N protein-induced expression of ICAM-1 and VCAM-1. Consistent 179 with the screening results, lovastatin showed mild effect on $\mathrm{N}$ protein-induced endothelial activation. The other 180 three statins did not affect $\mathrm{N}$ protein-induced endothelial activation. We further confirmed the effect of 181 simvastatin on $\mathrm{N}$ protein-induced endothelial activation in a dose-dependent manner (Fig.5b). Moreover, both 182 simvastatin and lovastatin treatments significantly inhibited $\mathrm{N}$ protein-induced NF- $\kappa \mathrm{B}$ activation (Fig.5c). 
183 Consistently, simvastatin pretreatment also blocked monocyte adhesion to the activated endothelial cells (Fig.5d).

184 Simvastatin is a member of the class of hexahydronaphthalenes like lovastatin in which the 2-methylbutyrate ester 185 moiety has been replaced by a 2,2-dimethylbutyrate ester group. Simvastatin is derived from lovastatin. 186 Lovastatin is a fatty acid ester that is mevastatin carrying an additional methyl group on the carbobicyclic 187 skeleton. The structures of simvastatin, lovastatin and mevastatin are very similar. Mevastatin does not have a 188 methyl group, however, both simvastatin and lovastatin have this group, which suggest that the group may be 189 important for its inhibitor effect on N protein-induced endothelial activation (Fig.6).

The N protein from SARS-CoV-2 but not the other coronaviruses potently induced endothelial cell activation

193 There are seven types of coronaviruses infecting humans including SARS-CoV-2, SARS-CoV, MERS-CoV, OC43-CoV, HKU1-CoV, 229E-CoV and NL63-CoV. The previous three are highly pathogenic and cause severe problems for humans. However, the later four are less pathogenic and only cause common cold. Though SARSCoV and MERS-CoV display high sequence similarity with SARS-CoV-2, the patients infected with SARS-CoV-

1972 are commonly affected by vascular injury and thrombosis formation ${ }^{25}$, which was not observed in the patients 198 infected with SARS-CoV and MERS-CoV. To understand the molecular basis of the pathogenesis, we compared 199 the effect of different N proteins from SARS-CoV-2, SARS-CoV, MERS-CoV, HKU1-CoV as well as H7N9 on 200 endothelial activation. Interestingly, as shown in Fig.7, only the N protein from SARS-CoV-2 potently induced 201 endothelial activation. The other N proteins, though their sequence is highly conserved, did not affect endothelial 202 activation (Fig.7). These results may explain why SARS-CoV-2-infected patients developed severe vascular 203 injury and thrombosis and affected many organs.

\section{DISCUSSION}

206 Coronavirus disease 2019 (COVID-19), caused by SARS-CoV-2, is a worldwide challenge for health care system. 207 The leading cause of mortality in patients with COVID-19 is ARDS and multi-organ failure. Emerging evidence 208 suggests that pulmonary endothelial cells contribute to the initiation and progression of ARDS by altering vessel 
barrier integrity, promoting a pro-coagulation state, inducing vascular inflammation (endotheliitis) and mediating inflammatory cell infiltration. However, the molecular mechanisms underlying SARS-CoV-2-induced endothelial

211 activation and vascular injury remain unclear. Though some reports indicated direct infection of endothelial cells

212 by SARS-CoV-2 in human samples, emerging evidence suggests that ACE2 is not highly expressed in human

213 endothelial cells and SARS-CoV-2 is not able to infect human endothelial cells in vitro ${ }^{26}$. Thus, the direct damage

214 of endothelial cells by SARS-CoV-2 infection cannot explain the broad endothelial dysfunction in COVID-19

215 patients. The possible mechanisms by which SARS-CoV-2 infection causes endothelial activation may be

216 attributed to the inflammatory and toxic roles of circulating viral proteins released from infected and lysed cells

217 and inflammatory cytokines secreted from inflammatory and immune cells.

218 In the manuscript, we have screened the recombinant SARS-CoV-2 viral proteins that are able to activate

219 human endothelial cells. We found that nucleocapsid protein ( $\mathrm{N}$ protein) of SARS-CoV-2 potently activate

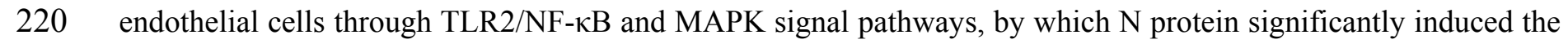

221 expression of ICAM-1 and VCAM-1 as well as other inflammatory cytokines and chemokines such as TNF $\alpha$, IL-

$2221 \beta$ and MCP-1. As ICAM-1 and VCAM-1 are major adhesion molecules expressed on activated endothelial cells

223 and mediated inflammatory cell infiltration into tissues, $\mathrm{N}$ protein may play a key role in the development of

224 ARDS and multi-organ injury.

The $\mathrm{N}$ protein is highly abundant in the viruses. Its function involves entering the host cells, binding to the viral RNA genome and forms the ribonucleoprotein core to facilitate its replication and process the virus particle assembly and release ${ }^{27}$. Previous reports showed that the N protein from SARS-CoV and MERS-CoV were highly inflammatory nature to promote the expression of inflammatory cytokines, chemokines, prothrombinase and were able to induce acute lung inflammation in mouse $\operatorname{model}^{28-30}$. The $\mathrm{N}$ protein from hantavirus Andes virus increased basal endothelial cell permeability by activating RhoA signaling ${ }^{31}$. The effect of N protein from SARS-CoV-2 on 231 host cells is less studied. In this manuscript, we report for the first time that the N protein from SARS-CoV-2 acts 232 as a pathogen-associated molecular pattern (PAMP) to direct bind to TLR2 and activate NF- $\mathrm{B}$ and MAPK 233 signaling. In an unbiased survey of phosphorylation landscape of SARS-CoV-2 infection, SARS-CoV-2 infection 234 is truly promoting activation of CK2 and p38 MAPK $^{32}$. Moreover, a recent human study showed that the serum 
levels of soluble ICAM-1 and VACM-1 were elevated in mild COVID-19 patients, dramatically elevated in severe cases, and decreased in the convalescence phase ${ }^{33}$. Taken together, the current study identified $\mathrm{N}$ protein as a potent factor to induce endothelial activation and provided the insights to understand the phenomenon of broad endothelial dysfunction and multi-organ injury that commonly appeared in severe COVID-19 patients.

induced endothelial activation. Several groups have raised the idea that statins can be used as early therapy to mitigate COVID-19-associated ARDS and cytokine storm syndrome ${ }^{34-36}$. Several recent reports showed that inhospital use of statins is associated with a reduced risk of mortality among individuals with COVID-19 ${ }^{37-39}$. There were more than 20 statins available in clinical use. We tested five different statins. Only simvastatin showed potent inhibitory activity on $\mathrm{N}$ protein-induced endothelial activation. Lovastatin also showed mild inhibitory potently suppressing endothelial activation.

Many patients with severe COVID-19 show signs of a cytokine storm ${ }^{41}$. The high levels of cytokines amplify

the destructive process by leading to EC activation, DIC, inflammation and vasodilation of the pulmonary capillary bed. This results in alveolar dysfunction, ARDS with hypoxic respiratory failure and ultimately multiorgan failure and death. EC dysfunction and activation likely co-determine this uncontrolled immune response. This is because ECs promote inflammation by expressing leukocyte adhesion molecules, thereby facilitating the accumulation and extravasation of leukocytes, including neutrophils and monocytes/macrophages, which enhance tissue damage. One recent report showed that SARS-CoV-2 N protein robustly induced proinflammatory cytokines/chemokines in human primary $\mathrm{PMBCs}^{42}$, suggesting that circulating $\mathrm{N}$ protein may also contribute to the initiation and progression of cytokine storm. Remarkably, though the protein sequences of N proteins from coronaviruses are highly conserved, only NP from SARS-CoV-2 induced endothelial activation. The NPs from 
261 other coronaviruses such as SARS-CoV, MERS-CoV, HKU1-CoV and influenza virus H1N1 did not affect

262 endothelial activation. Thus, these findings are well consistent with the results from clinical investigations.

263 In summary, our present study identified SARS-CoV-2 N protein as a potent inducer of human endothelial 264 activation, which can be specifically inhibited by simvastatin. The study provides insights on SARS-CoV-2265 induced vasculopathy and coagulopathy, and suggests that simvastatin, an FDA-approved lipid-lowering drug, 266 may benefit to prevent vascular pathogenesis and improve the outcome of COVID-19 patients.

\section{METHODS}

\section{Reagents}

270 SARS-CoV-2 nucleocapsid protein (NUN-C5227), S protein (SPN-C52H4) and envelope protein (ENN-C5128) 271 were from Acrobiosystems (Newark, DE). SARS-CoV-2 NSP1 (97-095), NSP5 (10-116), NSP7 (97-096) and 272 NSP8 (97-097) proteins were obtained from Prosci (Poway, CA). SARS-CoV-2 papain-like protease (DB604) 273 was purchased from Lifesensors (Malvern, PA). HCoV-HKU1 coronavirus nucleocapsid protein, H7N9 274 Nucleocapsid Protein (40110-V08B), MERS-CoV Nucleoprotein protein (40068-V08B) and SARS Coronavirus 275 Nucleocapsid Protein (40143-V08B) were from Sino biological (Beijing, China). Mammalian expression plasmid 276 for SARS-CoV-2 nucleocapsid protein (152536) was obtained from addgene (Watertown, MA). ICAM-1 (60299277 1-Ig) and GAPDH (60004-1-Ig) antibodies were from Proteintech (Rosemont, IL). VCAM-1 (sc-8304) and $\beta$ 278 actin (sc-47778) antibodies were obtained from Santa Cruz Biotechnology, Inc (Dallas, TX). SARS-CoV/SARS279 CoV-2 Nucleocapsid Antibody (40143-MM05) and SARS-CoV-2 Nucleocapsid antibody (40588-T62) were from 280 Sino biological (Beijing, China). The NF-kB and MAPK signal pathway antibodies were all from Cell Signaling 281 Technology (Danvers, MA).

\section{Cells}

284 Human umbilical vein endothelial cells (HUVEC), Human Aortic Endothelial Cells (HAEC), Human Coronary 285 Artery Endothelial Cells (HCAEC), Human Dermal Microvascular Endothelial Cells (HDMEC) and Human Lung 286 Microvascular Endothelial Cells (HLMEC) were purchased from Lonza Bioscience (Houston, TX). Mouse lung 
microvascular endothelial cells were obtained from Cell Biologics Inc (Chicago, IL). Cells were cultured in different endothelial cell growth medium in a humidified incubator with $5 \% \mathrm{CO}_{2}$ at $37^{\circ} \mathrm{C}$. Endothelial cells between passages 4 and 8 were grown as a monolayer and were used in all the experiments. HLMEC were treated with vehicle (PBS) or various SARS-CoV-2 proteins, including nucleocapsid protein (NP), S protein (SP), envelope protein (EP), NSP1, NSP3, NSP5, NSP7 and NSP8 at $1 \mu \mathrm{g} / \mathrm{mL}$ for $8 \mathrm{~h}$. In another set of experiment, HLMECs were treated with different coronavirus nucleocapsid proteins, including SARS-CoV-2 NP, SARS-CoV NP, MERS NP, H7N9 NP and HCoV-HKU1 NP at $1 \mu \mathrm{g} / \mathrm{mL}$ for $8 \mathrm{~h}$. Different subtypes of endothelial cells were 294 also used to observe the response to NP stimulation. For time course assay, HLMECs were incubated with 1 $295 \mu \mathrm{g} / \mathrm{mL}$ SARS-CoV-2 NP for 2 h, 4 h, 8 h, 16 h and 24 h, respectively. For dose-dependent assay, HLMECs were 296 treated with various concentrations of SARS-CoV-2 NP ranging from $0.01-10 \mu \mathrm{g} / \mathrm{mL}$. For NF- $\mathrm{kB}$ and MAPK 297 signal pathway assay, HLMECs were subject to SARS-CoV-2 NP exposure for $15 \mathrm{~min}, 30 \mathrm{~min}, 45 \mathrm{~min}, 1 \mathrm{~h}$ and 2 298 h, respectively. TNF $\alpha$ (10 ng/mL, PeproTech, Cranbury, NJ) was used in all above experiments as a positive 299 control of endothelial activation.

\section{Transfection of plasmids}

302 Flag-NP and Flag-control vectors were transfected to HLMEC by electroporation using Nucleofector device 303 (Lonza) and Nucleofector kits (Lonza, VPB-1002) following the manufacturer's instruction. The whole cell 304 lysates were harvested $48 \mathrm{~h}$ after electroporation and were analyzed by western blot.

\section{Chemical screening}

307 To screen for inhibitors of NP-induced endothelial activation, HLMECs were pretreated by $30 \mu \mathrm{M} / \mathrm{L}$ of individual 308 chemical from microbial natural product library (Target Molecule, Wellesley Hills, MA) for $1 \mathrm{~h}$ followed by 309 treatment of $1 \mu \mathrm{g} / \mathrm{ml}$ of $\mathrm{N}$ protein for $8 \mathrm{~h}$. The effect of chemicals on endothelial activation were measured by 310 ICAM-1 expression. To evaluate the inhibitory effects of statins on NP-induced endothelial activation, HLMECs 311 were pretreated with atovastatin, lovastatin, mevastatin, rosuvastatin or simvastatin (all from Biovision, Milpitas, 
$312 \mathrm{CA})$ for $1 \mathrm{~h}$ and followed by the treatment of $\mathrm{N}$ protein $(1 \mu \mathrm{g} / \mathrm{ml})$ for $8 \mathrm{~h}$. The whole cell lysates were harvested 313 and analyzed by western blot.

\section{Inhibitor treatment}

316 The antagonists or inhibitors involved in NF- $\mathrm{KB}$ and MAPK signal pathway were introduced to verify the action 317 of NP. The endocytosis inhibitors Pitstop $2(12.5 \mu \mathrm{M}$, Sigma) and Dynasore hydrate (12.5 $\mu \mathrm{M}$, Sigma), the TLR4 318 antagonist LPS-RS $(10 \mu \mathrm{g} / \mathrm{mL}$, InVivoGen, San Diego, CA), the TLR1/TLR2 antagonist CU-CPT22 (20 $\mu$ M, 319 Millipore, Burlington, MA), the IL-1R antagonist (20 $\mu \mathrm{M}$, Cayman Chemical Company), IKK-16 (20 $\mu \mathrm{M}$, 320 Cayman Chemical Company), the JNK inhibitor V (20 $\mu \mathrm{M}$, Cayman Chemical Company), the ERK1/2 inhibitor 321 U0126 (20 $\mu \mathrm{M}$, Cell Signal Technology), and the p38 inhibitor SB203580 (20 $\mu \mathrm{M}$, Enzo Life Sciences, 322 Farmingdale, NY) were added into HLMEC cultures $1 \mathrm{~h}$ before NP exposure. The whole cell lysates were 323 harvested $8 \mathrm{~h}$ after NP stimulation and analyzed by western blot.

\section{NP-induced NF-kB and MAPK activation in 293T-TLR2 cells}

293 T overexpressed human TLR2 was use to confirm the interaction between NP and TLR2, Wild type 293T and 293T-TLR2 (InVivoGen) cells were cultured in DMEM supplemented with 10\% FBS. The cells were treated with or without NP $(1 \mu \mathrm{g} / \mathrm{mL})$ for 15 mins. The cells were harvested and the whole cell lysates were subjected to detection of $\mathrm{pJNK}$ and $\mathrm{pP} 38$ by western blot.

\section{QPCR}

332 Total RNA was isolated from HLMEC after $8 \mathrm{~h}$ of NP exposure with the RNeasy Mini Kit (Qiagen, Germantown, 333 MD) according to the manufacturer's instructions. The first-strand cDNAs were synthesized by the High Capacity 334 RNA-to-cDNA Kit (Thermo Fisher Scientific, Vilnius, Lithuania). The reaction mixture contained $2 \times$ SYBR 335 Green PCR Master Mix (Applied Biosystems, Foster City, CA, USA), primer pairs and cDNAs. The reaction 336 consisted of a 2-step thermocycling protocol $\left(95^{\circ} \mathrm{C}\right.$ for $15 \mathrm{~s}$ and $60{ }^{\circ} \mathrm{C}$ for $1 \mathrm{~min} ; 40$ cycles $)$. The mRNA levels 
337 were calculated by using the $2^{-\Delta \Delta C T}$ method. The Primer sequences used in the experiment were listed in Table S1.

338 Results were obtained from at least three biological replications performed in triplicate.

\section{Western blot}

341 The total protein was collected with ice cold RIPA lysis buffer after NP stimulation. Equal amounts of protein 342 were loaded into the wells of the SDS-PAGE gel and separated by electrophoresis. Then the protein were 343 transferred to the PVDF membrane. The 5\% (w/v) skim milk were used to block the un-specific binding. 344 Membranes were incubated with different primary antibodies at $4{ }^{\circ} \mathrm{C}$ overnight, followed by incubation with 345 HRP-conjugated secondary antibodies for $1 \mathrm{~h}$ at room temperature. Luminescence was generated after the 346 membranes were exposed to Super Signal West Pico Chemiluminescent Substrate (Thermo Fisher Scientific) and 347 was detected with X-ray film.

\section{Monocyte adhesion assay}

350 Monocyte adhesion was analyzed as previously described ${ }^{43}$, with some modification. HLMECs were stimulated 351 with NP or TNF- $\alpha$ for $8 \mathrm{~h}$. The human acute monocytic leukemia cell line THP-1 (Lonza) was prelabeled with 352 Zombie Red fluorescent dye (Biolegend, San Diego, CA) in RPMI-1640 medium for 30 min at $37^{\circ} \mathrm{C}$ before being 353 added to HLMECs and co-cultured for $1 \mathrm{~h}$. Non-adherent cells were removed by gently washing with cold RPMI3541640 medium. The images of adherent THP-1 cells were taken under Cytation 3 Cell Imaging Multi-mode 355 Reader.

\section{Statistical Analyses}

358 Data were obtained from at least three independent experiments and were represented as mean \pm SD. Statistical 359 differences were compared using one-way ANOVA followed by a Tukey post hoc test. An unpaired Student's t360 test was performed to compare data between two independent groups. A difference with $\mathrm{P}<0.05$ was considered 361 statistically significant. A p-value less than 0.05 was considered statistically significant. 


\section{ACKNOWLEDGMENTS}

364 We thank Dr. Peter Klein (University of Pennsylvania) for providing SARS-CoV2 Nucleocapsid plasmid via

365 Addgene.com. This work was supported by National Institutes of Health Grant AI138116 (to M.F). J.Q. was 366 supported by National Institute of Health Grant AI150877 and AI144564. Y.Q was supported by China 367 Scholarship Council (20190682503)

369 AUTHOR CONTRIBUTIONS

370 M.F. and Y. Q designed the research and analyzed data; Y.Q., T.L., and P.P did the experiments; C.L, P.N., J.Q 371 and H-B. X provided advice and critically read the manuscript; M.F and Y.Q wrote the manuscript.

\section{DECLEARE OF CONFLICT OF INTERESTS}

374 The authors have no conflict of interests to declare.

\section{REFERENCES}

377 1. Ackermann, M., Verleden, S.E., Kuehnel, M., Haverich, A., Welte, T., et al. Pulmonary Vascular 378 Endothelialitis, Thrombosis, and Angiogenesis in Covid-19. N. Engl. J. Med. 383, 120-128 (2020).

379 2. Kirtipal, N., Bharadwaj, S., Kang, S.G. From SARS to SARS-CoV-2, insights on structure, pathogenicity and 380 immunity aspects of pandemic human coronaviruses. Infect. Genet. Evol. 85, 104502 (2020).

381 3. de Wit, E., van Doremalen, N., Falzarano, D., Munster, V.J. SARS and MERS: recent insights into emerging 382 coronaviruses. Nat. Rev. Microbiol. 14, 523-34 (2016).

383 4. Liu, D.X., Fung, T.S., Chong, K.K., Shukla, A., Hilgenfeld, R. Accessory proteins of SARS-CoV and other 384 coronaviruses. Antiviral Res. 109, 97-109 (2014).

385 5. Guan, W.J., Ni, Z.Y., Hu, Y., Liang, W.H., Ou, C.Q., et al. Clinical Characteristics of Coronavirus Disease 3862019 in China. N. Engl. J. Med. 382, 1708-1720 (2020).

387 6. Carnevale, S., Beretta, P., Morbini, P. Direct endothelial damage and vasculitis due to SARS-CoV-2 in small 388 bowel submucosa of COVID-19 patient with diarrhea. J. Med. Virol. 10, 1002 (2020). 
7. Vrints, C.J.M., Krychtiuk, K.A., Van Craenenbroeck, E.M., Segers, V.F., Price, S., Heidbuchel, H.

390 Endothelialitis plays a central role in the pathophysiology of severe COVID-19 and its cardiovascular

391 complications. Acta. Cardiol. 2, 1-16(2020).

392 8. Fraser, D.D., Patterson, E.K., Slessarev, M., Gill, S.E., Martin, C., et al. Endothelial Injury and Glycocalyx 393 Degradation in Critically Ill Coronavirus Disease 2019 Patients: Implications for Microvascular Platelet 394 Aggregation. Crit, Care Explor. 2, e0194 (2020).

395 9. Guervilly, C., Burtey, S., Sabatier, F., Cauchois, R., Lano, G., et al. Circulating Endothelial Cells as a Marker 396 of Endothelial Injury in Severe COVID -19. J. Infect. Dis. 222, 1789-1793 (2020).

397 10. Huertas, A., Montani, D., Savale, L., Pichon, J., Tu, L., et al. Endothelial cell dysfunction: a major player in 398 SARS-CoV-2 infection (COVID-19)? Eur. Respir. J. 56, 2001634 (2020).

399 11. Lei, Y., Zhang, J., Schiavon, C.R., He, M., Chen, L., et al. SARS-CoV-2 Spike Protein Impairs Endothelial 400 Function via Downregulation of ACE2. bioRxiv. 12, 04.409144 (2020).

401 12. Wang, P., Luo, R., Zhang, M., Wang, Y., Song, T., et al. A cross-talk between epithelium and endothelium 402 mediates human alveolar-capillary injury during SARS-CoV-2 infection. Cell Death Dis. 11, 1042 (2020).

403 13. Teuwen, L.A., Geldhof, V., Pasut, A., Carmeliet, P. COVID-19: the vasculature unleashed. Nat. Rev. 404 Immunol. 20, 389-391 (2020).

405 14. Pons, S., Fodil, S., Azoulay, E., Zafrani, L. The vascular endothelium: the cornerstone of organ dysfunction in severe SARS-CoV-2 infection. Crit. Care. 24, 353 (2020).

407 15. Lan, J., Ge, J., Yu, J., Shan, S., Zhou, H., et al. Structure of the SARS-CoV-2 spike receptor-binding domain 408 bound to the ACE2 receptor. Nature. 581, 215-220 (2020).

409 16. Albini, A., Di Guardo, G., Noonan, D.M., Lombardo, M. The SARS-CoV-2 receptor, ACE-2, is expressed 410 on many different cell types: implications for ACE-inhibitor- and angiotensin II receptor blocker-

411 based cardiovascular therapies. Intern Emerg. Med. 15, 759-766 (2020).

412 17. Bhatnagar, J., Gary, J., Reagan-Steiner, S., Estetter, L.B., Tong, S., et al. Evidence of SARS-CoV-2 413 Replication and Tropism in the Lungs, Airways and Vascular Endothelium of Patients with Fatal COVID-19: An 414 Autopsy Case-Series. J Infect Dis. 27, jiab039 (2021). 
415 18. Korakas, E., Ikonomidis, I., Kousathana, F., Balampanis, K., Kountouri, A., et al. Obesity and COVID-19:

416 immune and metabolic derangement as a possible link to adverse clinical outcomes. Am. J. Physiol. Endocrinol.

417 Metab. 319, E105-E109 (2020).

418 19. Lu, R., Zhao, X., Li, J., Niu, P., Yang, B., et al. Genomic characterisation and epidemiology of 2019 novel 419 coronavirus: implications for virus origins and receptor binding. Lancet. 395, 565-574 (2020).

420 20. Forster, P., Forster, L., Renfrew, C., Forster, M. Phylogenetic network analysis of SARS-CoV-2 genomes.

421 Proc. Natl. Acad. Sci. U S A. 117, 9241-9243 (2020).

422 21. Wawryk, S.O., Novotny, J.R., Wicks. I.P., Wilkinson. D., Maher. D., et al. The role of the LFA-1/ICAM-1

423 interaction in human leukocyte homing and adhesion. Immunol. Rev. 108, 135-61 (1989).

424 22. Yong, K., Khwaja, A. Leucocyte cellular adhesion molecules. Blood Rev. 4, 211-25 (1990).

425 23. Fusté, B., Mazzara, R., Escolar, G., Merino, A., Ordinas, A., Díaz-Ricart, M. Granulocyte colony-

426 stimulating factor increases expression of adhesion receptors on endothelial cells through activation of p38

427 MAPK. Haematologica. 89, 578-85 (2004).

428 24. Iademarco, M.F., McQuillan, J.J., Rosen, G.D., Dean. D,C. Characterization of the promoter for vascular

429 cell adhesion molecule-1 (VCAM-1). J. Biol. Chem. 267, 16323-9 (1992).

431 25. Rodríguez, C., Luque, N., Blanco, I., Sebastian, L., Barberà, J.A., et al. Pulmonary Endothelial Dysfunction 432 and Thrombotic Complications in COVID-19 Patients. Am. J. Respir. Cell Mol. Biol. 2020 Nov 12. doi: $433 \quad 10.1165 / \mathrm{rcmb} .2020-0359 P S$.

434 26. Nascimento, C.J., Schutt, W.R., Gorbunova, E.E., Mackow, E.R. Recombinant ACE2 Expression Is 435 Required for SARS-CoV-2 To Infect Primary Human Endothelial Cells and Induce Inflammatory and 436 Procoagulative Responses. mBio. 11, e03185-20 (2020).

437 27. Khan, A., Tahir Khan, M., Saleem, S., Junaid, M., Ali, A., et al. Structural insights into the mechanism of 438 RNA recognition by the N-terminal RNA-binding domain of the SARS-CoV-2 nucleocapsid phosphoprotein.

439 Comput. Struct. Biotechnol. J. 18, 2174-2184 (2020).

440 28. Chang, C.K., Hou, M.H., Chang, C.F., Hsiao, C.D., Huang, T.H. The SARS coronavirus nucleocapsid 441 protein--forms and functions. Antiviral Res. 103, 39-50 (2014). 
29. Aboagye, J.O., Yew, C.W., Ng, O.W., Monteil, V.M., Mirazimi, A., Tan, Y.J. Overexpression of the

443 nucleocapsid protein of Middle East respiratory syndrome coronavirus up-regulates CXCL10. Biosci. Rep. 38, 444 BSR20181059(2018).

445 30. Zhu, Y.G., Qu, J.M. Differential characteristics of the early stage of lung inflammation induced by SARS446 CoV Nucleocapsid protein related to age in the mouse. Inflamm. Res. 58, 312-20 (2009).

447 31. Gorbunova, E.E., Simons, M.J., Gavrilovskaya, I.N., Mackow, E.R. The Andes Virus Nucleocapsid Protein 448 Directs Basal Endothelial Cell Permeability by Activating RhoA. mBio. 7, e01747-16 (2016).

449 32. Bouhaddou, M., et al. The Global Phosphorylation Landscape of SARS-CoV-2 Infection. Cell. 182, 685$450 \quad 712 . \mathrm{e} 19(2020)$.

451 33. Tong, M., Jiang, Y., Xia, D., Xiong, Y., Zheng, Q., et al. Elevated Expression of Serum Endothelial Cell 452 Adhesion Molecules in COVID-19 Patients. J. Infect. Dis. 222, 894-898 (2020).

453 34. Gordon, D. Statins may be a key therapeutic for Covid-19. Med. Hypotheses. 144, 110001 (2020).

454 35. Lima Martínez, M.M., Contreras, M.A., Marín, W., D'Marco, L. Statins in COVID-19: is there any 455 foundation? Clin. Investig. Arterioscler. 32, 278-281 (2020).

456 36. Teoh, N., Farrell, G. Statins as early therapy to mitigate COVID-19 (SARS-CoV-2)-associated ARDS and 457 cytokine storm syndrome - time is of the essence. J. Clin. Transl. Res. 5, 227-229 (2020).

458 37. Tan, W.Y.T., Young, B.E., Lye, D.C., Chew, D.E.K., Dalan, R. Statin use is associated with lower disease 459 severity in COVID-19 infection. Sci. Rep. 10, 17458 (2020).

460 38. Zhang, X.J., Qin, J.J., Cheng, X., Shen, L., Zhao, Y.C., et al. In-Hospital Use of Statins Is Associated with a 461 Reduced Risk of Mortality among Individuals with COVID-19. Cell Metab. 32, 176-187.e4 (2020).

462 39. Bifulco, M., Gazzerro, P. Statin therapy in COVID-19 infection: much more than a single pathway. Eur. 463 Heart J. Cardiovasc. Pharmacother. 6, 410-411 (2020).

464 40. Crespo, M.J., Quidgley, J. Simvastatin, atorvastatin, and pravastatin equally improve the hemodynamic 465 status of diabetic rats. World J. Diabetes. 6, 1168-78 (2015).

466 41. Wang, J., Jiang, M., Chen, X., Montaner, L.J. Cytokine storm and leukocyte changes in mild versus severe 467 SARS-CoV-2 infection: Review of 3939 COVID-19 patients in China and emerging pathogenesis and therapy 468 concepts. J. Leukoc. Biol. 108, 17-41 (2020). 
469 42. Sohn, K.M., Lee, S.G., Kim, H.J., Cheon, S., Jeong, H., et al. COVID-19 Patients Upregulate Toll-like

470 Receptor 4-mediated Inflammatory Signaling That Mimics Bacterial Sepsis. J. Korean Med. Sci. 35, e343

471 (2020).

472 43. Li, Y., Huang, X., Guo, F., Lei, T., Li, S., et al. TRIM65 E3 ligase targets VCAM-1 degradation to limit 473 LPS-induced lung inflammation. J. Mol. Cell Biol. 12, 190-201 (2020). 
a

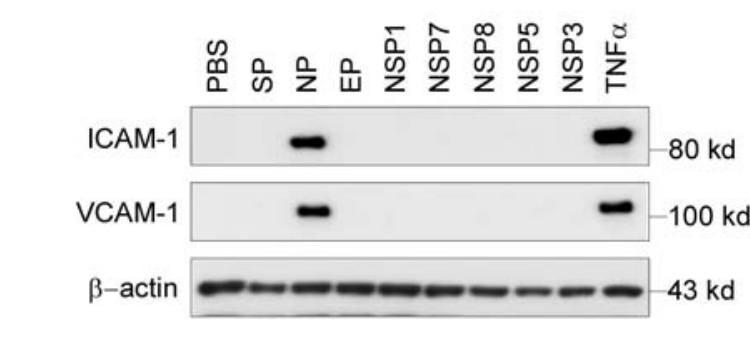

C

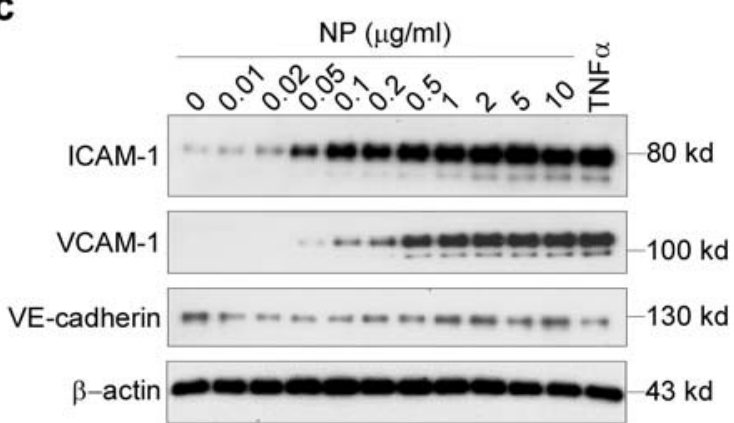

b

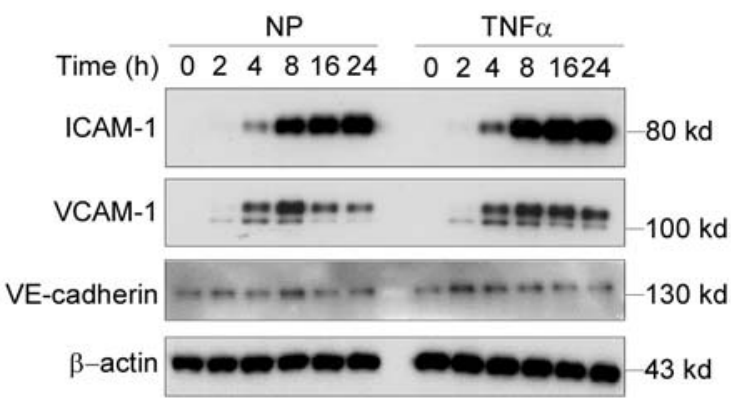

d

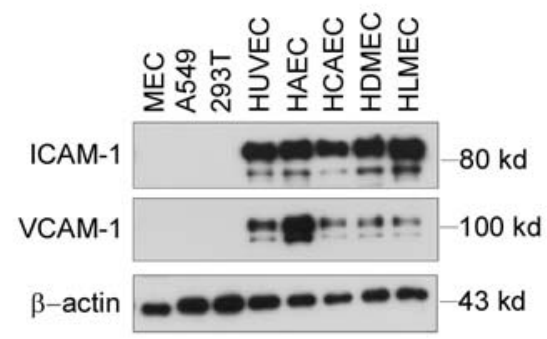

e

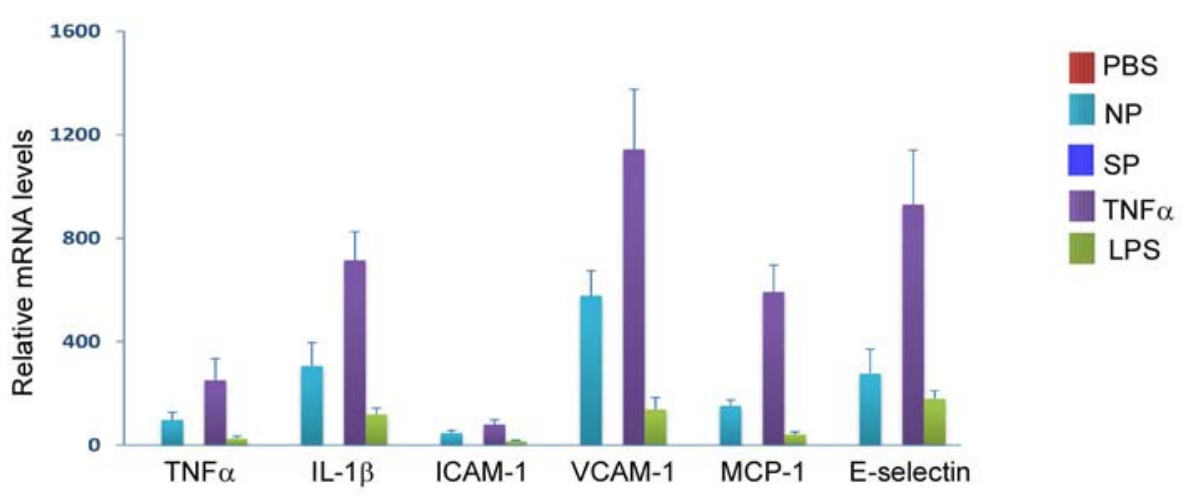

f
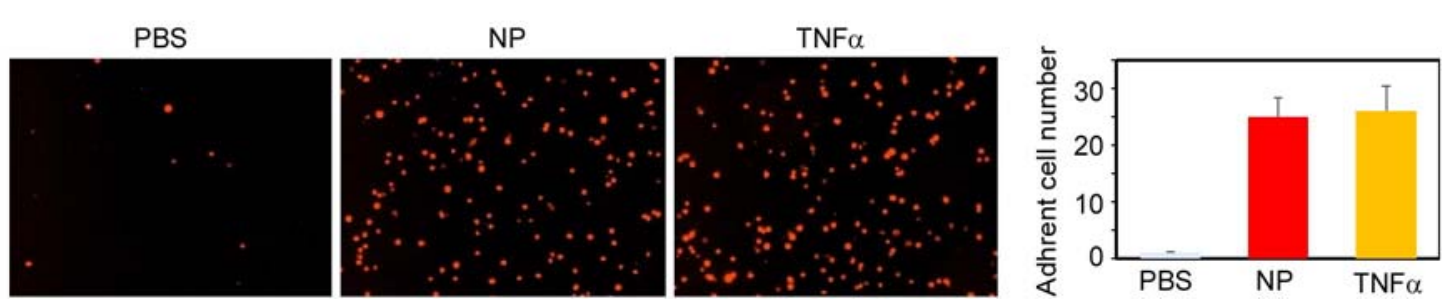

Figure 1. SARS-CoV2 nucleocapsid protein (NP) is a potent inducer of human endothelial cell activation. (a) HLMECs were incubated with SARS-CoV2 structural proteins $(\mathrm{S}, \mathrm{N}$, and E proteins, $1 \mu \mathrm{g} / \mathrm{mL})$ and five non-structural proteins (NSP1, NSP3, NSP5, NSP7 and NSP8, $1 \mu \mathrm{g} / \mathrm{mL}$ ) for 8 hrs. (b) HLMECs were treated with $1 \mu \mathrm{g} / \mathrm{mL}$ of NP or $10 \mathrm{ng} / \mathrm{ml}$ of $\mathrm{TNF} \alpha$ for different incubation periods as indicated. (c) HLMECs were incubated with indicated concentrations of NP for $8 \mathrm{hrs} .10 \mathrm{ng} / \mathrm{ml}$ of TNF $\alpha$ serves as positive control. (d) Different cultured cells including mouse lung vascular endothelial cells (MEC), A549, 293T, HUVEC, HAEC, HCAEC, HDMEC and HLMEC were treated with NP $(1 \mu \mathrm{g} / \mathrm{mL})$ for $8 \mathrm{hrs}$. The expression of ICAM-1, VCAM1 and VE-cadherin was detected by western blot. $\beta$-actin was served as loading control. (e) HLMECs were treated with PBS, NP $(1 \mu \mathrm{g} / \mathrm{ml})$, TNF $\alpha(10 \mathrm{ng} / \mathrm{ml})$ or LPS $(1 \mu \mathrm{g} / \mathrm{ml})$ for 8 hours. The total RNA was isolated and QPCR was performed for measuring the mRNA levels of TNF $\alpha$, ICAM-1, VCAM-1, MCP-1 and IL-6. (f) HLMECs were treated with PBS, NP $(1 \mu \mathrm{g} / \mathrm{ml})$ or TNF $\alpha(10 \mathrm{ng} / \mathrm{ml})$ for 8 hours and co-cultured with Zombie Red-labeled THP-1 cells for $1 \mathrm{~h}$. After washing, the adherent cells were imaged and quantitatively analyzed. 
NP $(1 \mu \mathrm{g} / \mathrm{mL})$

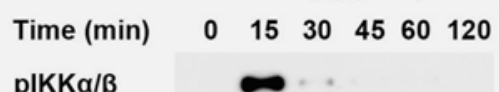

pIKKa/ $\beta$

IKKa $\quad-\infty-\infty$

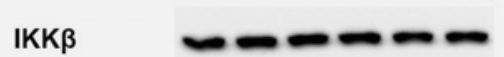

p-p65

p65

plкB $\alpha$

IKBa

GAPDH
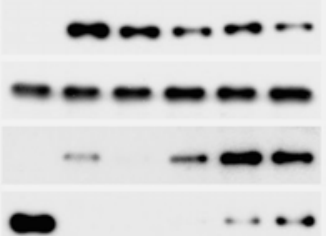

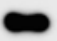

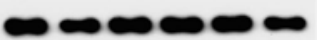

SP $(1 \mu \mathrm{g} / \mathrm{mL})$

$\begin{array}{llllll}0 & 15 & 30 & 45 & 60 & 120\end{array}$
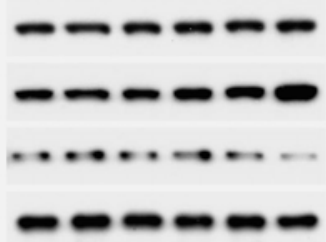

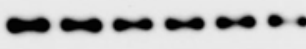
(2)
TNFa (10 ng/mL)

$\begin{array}{llllll}0 & 15 & 30 & 45 & 60 & 120\end{array}$
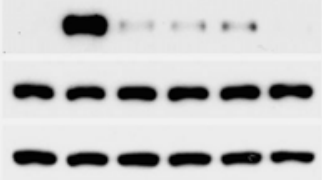

$\hookrightarrow-\infty$

$\cdots$ $\ldots \omega$

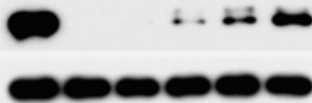

$\begin{array}{llllll}0 & 15 & 30 & 45 & 60 & 120\end{array}$

$200=3=$

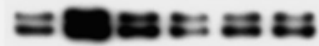

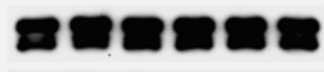

ERK

pJNK

JNK

pp38

p38

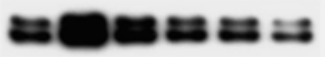
무를

- - - .

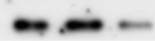

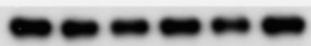

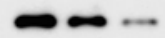

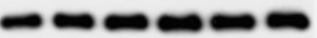

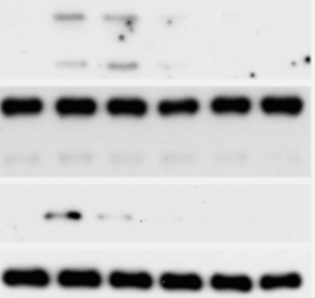

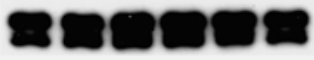

$0=\cdots$ $\rightarrow-\ldots$ :

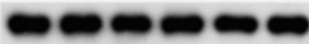

(2)

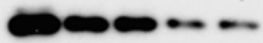

-
LPS $(1 \mu \mathrm{g} / \mathrm{mL})$

$\begin{array}{llllll}0 & 15 & 30 & 45 & 60 & 120\end{array}$

$0-\infty-\infty$

$-\infty-\infty$

$-\infty \infty$

$-\infty \omega \infty$

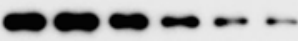
ఝల6)

Figure. 2. $\mathrm{N}$ protein activated $\mathrm{NF}-\kappa \mathrm{B}$ and MAPK signaling pathways in human endothelial cells. HLMECs were incubated with NP $(1 \mu \mathrm{g} / \mathrm{ml})$, SP $(1 \mu \mathrm{g} / \mathrm{ml})$, TNF $\alpha(10 \mathrm{ng} / \mathrm{ml})$ and LPS $(1 \mu \mathrm{g} / \mathrm{ml})$ respectively for indicated times. The phosphorylation of IKKs, p65, I $\kappa \mathrm{B} \alpha, \mathrm{ERK}, \mathrm{JNK}$ and p38, as well as I $\mathrm{B} \alpha$ degradation were detected by western blot. GAPDH was served as loading control. 
a

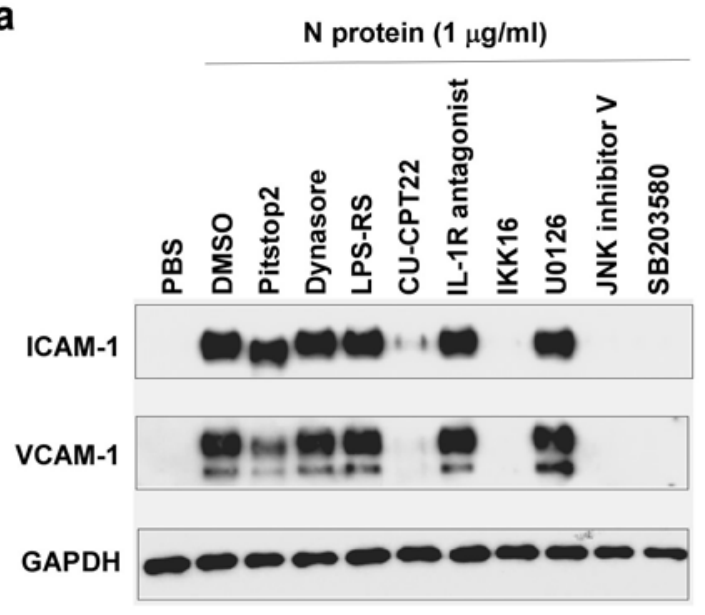

C

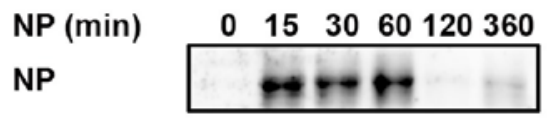

$\beta$-actin

d

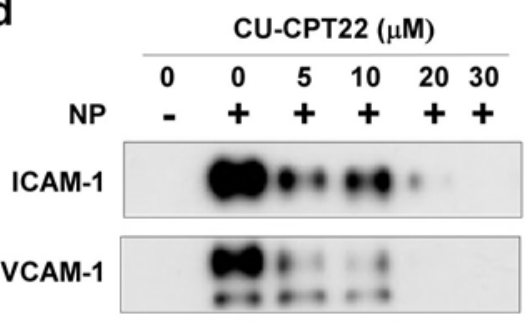

GAPDH

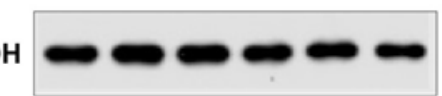

b

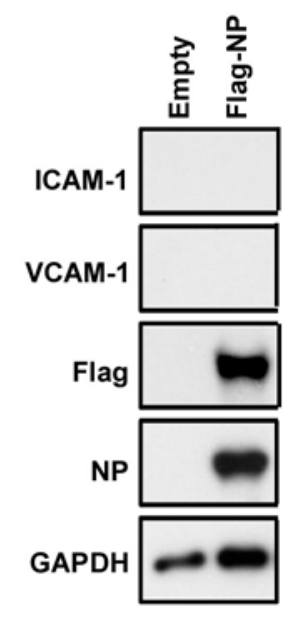

e

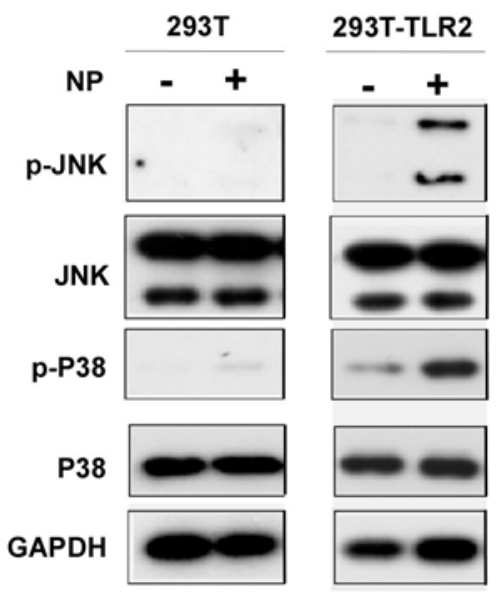

Figure. 3. $\mathbf{N}$ protein induced endothelial cell activation via TLR2-mediated signaling pathway. (a) HLMECs were pretreated with inhibitors of endocytosis (Pitstop2, $12.5 \mu \mathrm{M}$ and Dynasore hydrate, $12.5 \mu \mathrm{M}$ ) and antagonists of TLR4 (LPS-RS, $10 \mu \mathrm{g} / \mathrm{mL}$ ), TLR2 (CU-CPT22, $20 \mu \mathrm{M}$ ), IL-1R (IL-1R antagonist, $20 \mu \mathrm{M}$ ), inhibitors of IKK (IKK16, $20 \mu \mathrm{M}$ ), ERK (U0126, $20 \mu \mathrm{M})$, JNK (JNK inhibitor V, $20 \mu \mathrm{M})$ and p38 (SB203580, $20 \mu \mathrm{M})$ for $1 \mathrm{~h}$ followed by treatment with NP $(1 \mu \mathrm{g} / \mathrm{mL})$ for $8 \mathrm{hrs}$. (b) The Flag control and Flag-NP expression plasmids were transfected into HLMECs by electroporation respectively. The whole cell lysate was harvested after $48 \mathrm{~h}$ transfection. The expression of ICAM-1, VCAM-1, NP and Flag was detected by western blot. (c) HMVECs were incubated with NP $(1 \mu \mathrm{g} / \mathrm{mL})$ for different time as indicated. After washing, the cells were harvested and NP was detected by western blot. (d) HLMECs were treated with indicated concentrations of CUCPT22 for $1 \mathrm{~h}$ followed by treatment of NP $(1 \mu \mathrm{g} / \mathrm{mL})$ for $8 \mathrm{hrs}$. (e) Wild type (left) and TLR2-overexpressed $293 \mathrm{~T}$ cells were treated with or without NP $(1 \mu \mathrm{g} / \mathrm{mL})$ for $15 \mathrm{~min}$. The pJNK and pP38 were detected by western blot. GAPDH was served as loading control. All of experiments have been repeated at least one time. 
bioRxiv preprint doi: https://doi.org/10.1101/2021.02.14.431174; this version posted February 18, 2021. The copyright holder for this preprint (which was not certified by peer review) is the author/funder, who has granted bioRxiv a license to display the preprint in perpetuity. It is made available under aCC-BY-NC-ND 4.0 International license.
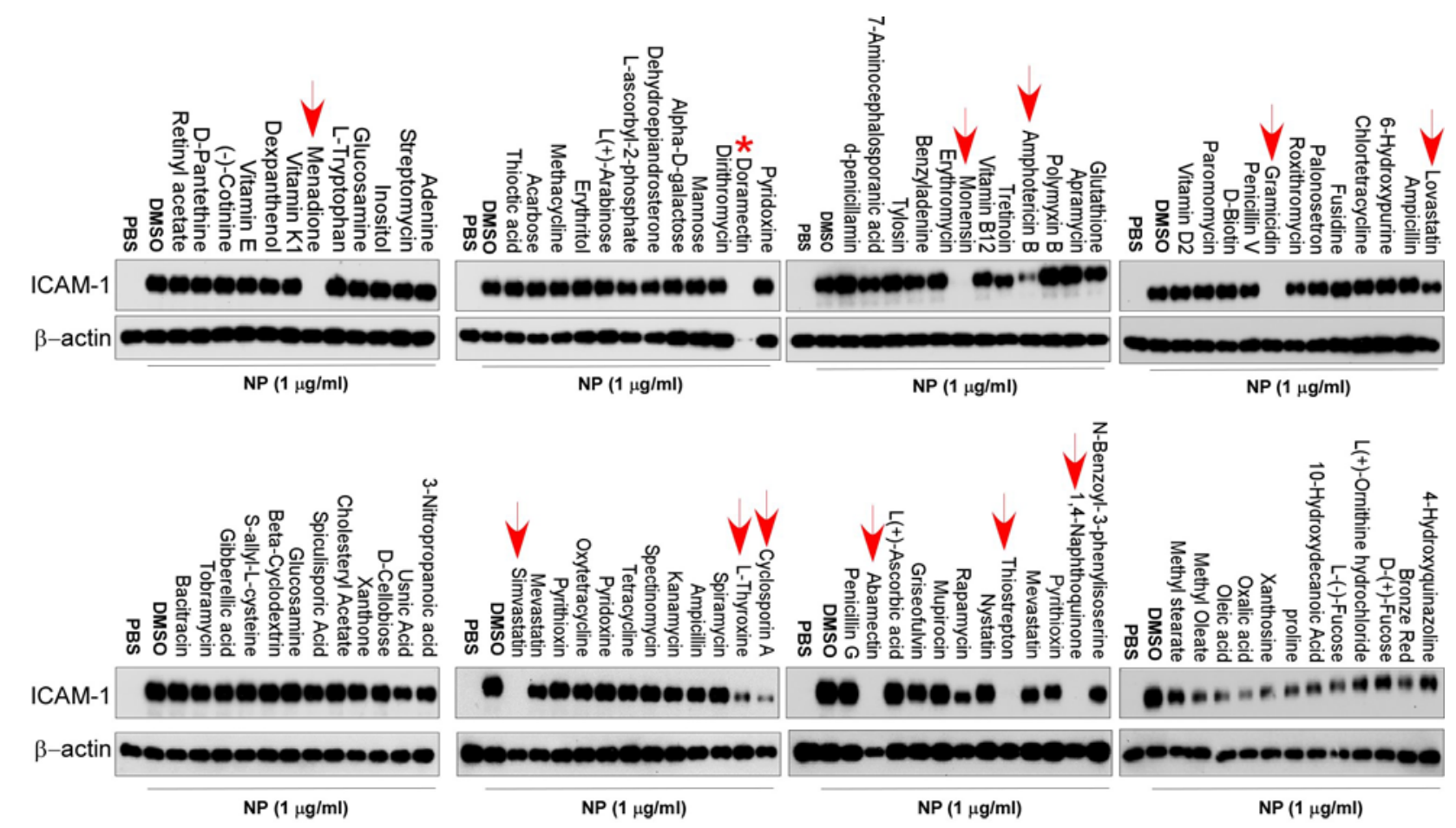

Figure. 4. Screening of chemicals for inhibition of $\mathbf{N}$ protein-induced endothelial activation. A total of 155 chemicals from microbial natural product library were added into HLMECs at $30 \mu \mathrm{M} 1$ hour before the induction of $\mathrm{N}$ protein $(1 \mu \mathrm{g} / \mathrm{ml})$. The effect of chemicals on endothelial activation was measured by Western blot with anti-ICAM-1 antibody. $\beta$-actin was served as loading control. Arrow points out the effective compounds; stars point out the toxic compounds causing cell death. The experiments has been repeated for one more time. 
a

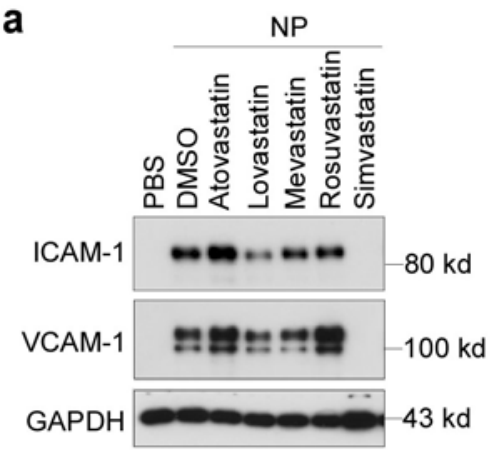

b

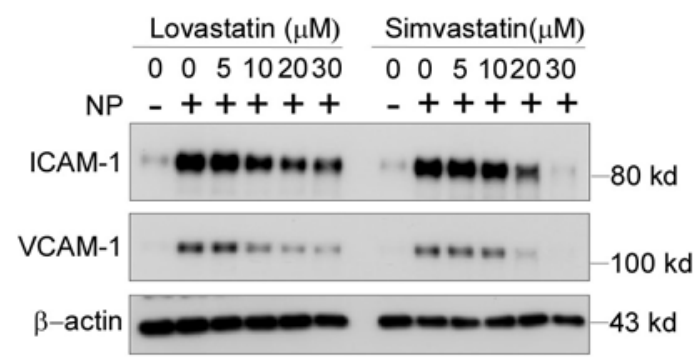

C

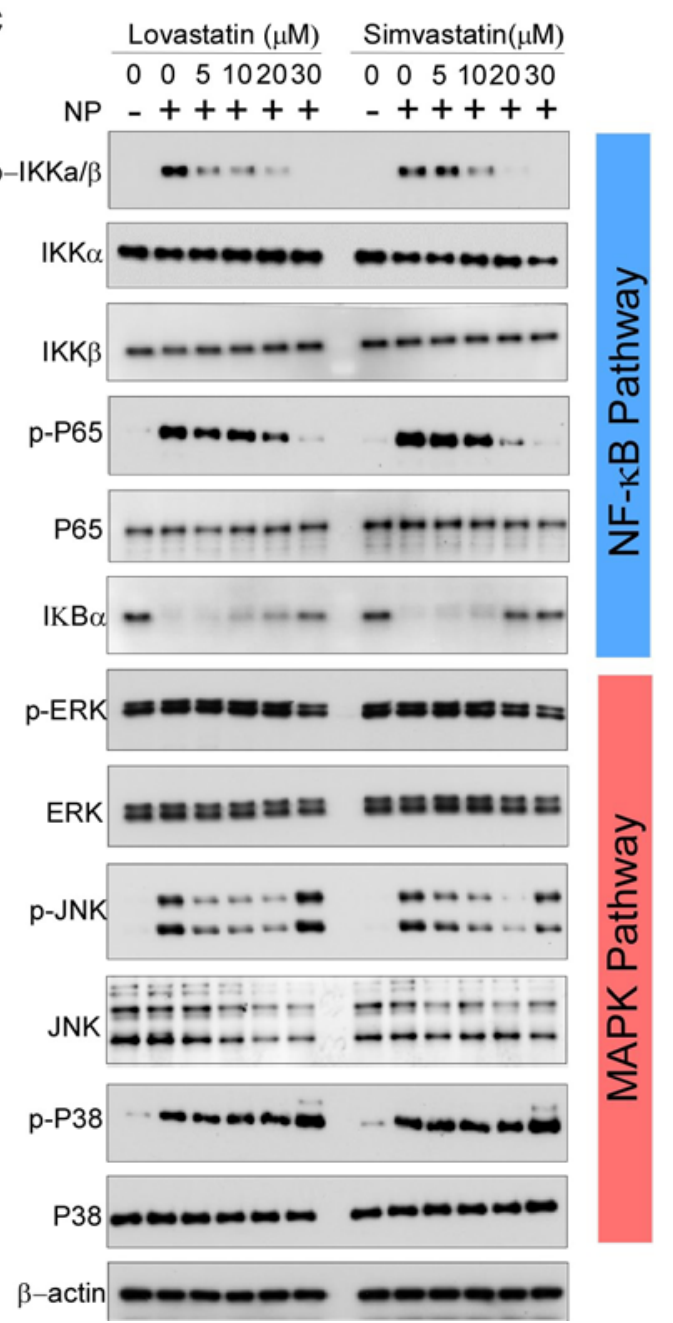

d
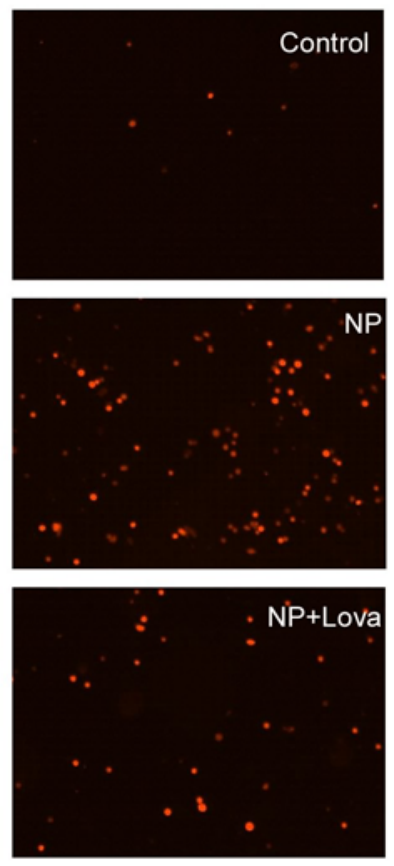

NP+Simva

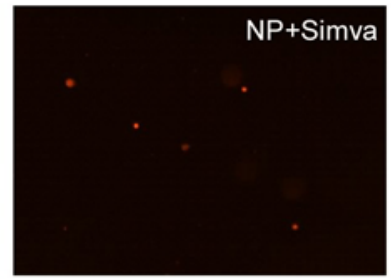

Figure. 5. Simvastatin is an effective inhibitor of $\mathbf{N}$ protein-induced endothelial activation in vitro. (a) HLMECs were pretreated with simvastatin, lovastatin, atorvastatin, mevastatin and rosuvastatin at $30 \mu \mathrm{M}$ for 1 $\mathrm{h}$ followed by treatment with NP $(1 \mu \mathrm{g} / \mathrm{mL})$ for $8 \mathrm{hrs}$. (b) HLMECs were pretreated with indicated concentrations of Lovastatin and Simvastatin for $1 \mathrm{~h}$ followed by treatment with NP $(1 \mathrm{\mu} \mathrm{g} / \mathrm{mL})$ for $8 \mathrm{hrs}$. The expression of ICAM-1 and VCAM-1 was detected by western blot. (c) HLMECs were pretreated with indicated concentrations of Lovastatin and Simvastatin for $1 \mathrm{~h}$ by treatment with NP $(1 \mu \mathrm{g} / \mathrm{mL})$ for 15 mins. The activation of NF- $\kappa$ B and MAPK signal pathways was detected by western blot. (d) HLMECs were pretreated with or without Lovastatin (Lova) or Simvastatin (Simva) followed by treatment with NP $(1 \mu \mathrm{g} / \mathrm{ml})$ for 8 hours and then co-cultured with Zombie Red-labeled THP-1 cells for $1 \mathrm{~h}$. After washing, the adherent cells were 580 imaged. 
<smiles>CCC(C)(C)C(=O)O[C@H]1C[C@@H](C)C=C2C=C[C@H](C)[C@H](CC[C@H]3C[C@H](O)CC(=O)O3)[C@H]21</smiles>

Simvastatin<smiles>CC[C@H](C)C(=O)O[C@H]1C[C@H](C)C=C2C=C[C@H](C)[C@H](CC[C@H]3C[C@@H](O)CC(=O)O3)[C@H]21</smiles>

Lovastatin<smiles>CC[C@H](C)C(=O)O[C@H]1CCC=C2C=C[C@H](C)[C@H](CC[C@@H]3C[C@@H](O)CC(=O)O3)[C@H]2[C@H]1C</smiles>

Mevastatin<smiles>CC(C)c1c(C(=O)Nc2ccccc2)c(-c2ccccc2)c(-c2ccc(F)cc2)n1CC[C@H](O)C[C@@H](O)CC(=O)O</smiles>

Atorvastatin<smiles>CC(C)c1nc(N(C)S(C)(=O)=O)nc(-c2ccc(F)cc2)c1/C=C/[C@@H](O)C[C@@H](O)CC(=O)O</smiles>

Rosuvastatin

Figure. 6. Chemical structures of Simvastatin, Lovastatin, Mevastatin, Atovastatin and Rosuvastatin (adapted 


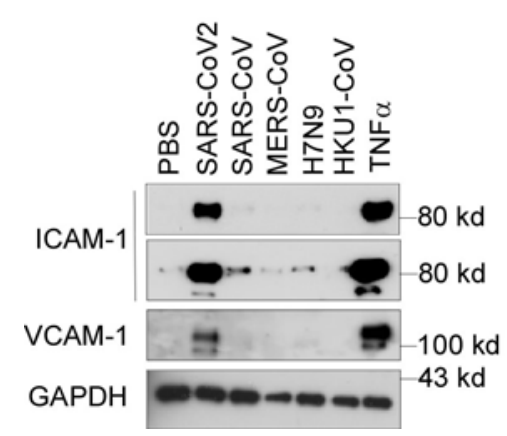

Figure. 7. The N protein from SARS-CoV2 but not the other coronaviruses potently induced endothelial cell activation. HLMECs were treated with or without five different recombinant viral $\mathrm{N}$ proteins $(1 \mu \mathrm{g} / \mathrm{mL})$ including SARS-CoV2, SARS-CoV, MERS-CoV, H7N9 and HKU1-CoV for 8 hrs. The expression of ICAM-1 and VCAM-1 was detected by western blot. TNF $\alpha(10 \mathrm{ng} / \mathrm{mL})$ was served as a positive control. GAPDH was served as loading control. The experiments were repeated at least one more time. 
bioRxiv preprint doi: https://doi.org/10.1101/2021.02 14.431174. this version posted February 18,2021 . The copyright holder for this preprint (which was not certified by peer review) is the author/funder, who has granted bioRxiv a license to display the preprint in perpetuity. It is made available under aCC-BY-NC-ND 4.0 International license.

661 Table S1. Primers used in QPCR reactions

662

\begin{tabular}{lll}
\hline Gene & Forward primer $\left(5^{\prime} \rightarrow 3^{\prime}\right)$ & Reverse primer $\left(5^{\prime} \rightarrow 3^{\prime}\right)$ \\
\hline Human ICAM-1 & AGCTTCGTGTCCTGTATGGC & TTTTCTGGCCACGTCCAGTT \\
Human VCAM-1 & TGTTTGCAGCTTCTCAAGCTTTT & GATGTGGTCCCCTCATTCGT \\
Human TNF- $\alpha$ & TCTCGCACCCCGAGTGA & GGAGCTGCCCCTCAGCTT \\
Human MCP1 & CAGCCAGATGCAATCAATGCC & TGGAATCCTGAACCCACTTCT \\
Human IL-1 $\beta$ & CCACAGACCTTCCAGGAGAATG & ATCCCATGTGTCGAAGAAGATAGG \\
Human E-Selectin & GGCAGTTCCGGGAAAGATCA & GTGGGAGCTTCACAGGTAGG \\
\hline
\end{tabular}

